\title{
FINANCIAL COMPENSATION, NON-PHYSICAL WORKING ENVIRONMENT, AND ORGANIZATIONAL COMMITMENT ON EMPLOYEE WORK SPIRIT
}

\author{
FAADILLAH ADHIRAJASA \\ KAREL TJAHJADI \\ Trisakti School of Management, Jl. Kyai Tapa No. 20, Jakarta, Indonesia \\ adhirajasa10@gmail.com, kareltjahjadi@yahoo.com
}

\begin{abstract}
Abstact: The purpose of this study is to see compensation compensation, non-physical work environment, and organizational commitment to employee morale. The research was conducted at PT Sorik Marapi Geothermal Power Jakarta. The number of samples taken was 70 employees, with the saturation / census sample method. Data were collected through a questionnaire. The analysis technique uses multiple linear regression analysis techniques. Initial observations found that PT Sorik Marapi Geothermal Power Jakarta had problems related to employee morale. This condition can be seen from the high level of employee absenteeism. Based on the analysis, it is known that financial compensation, non-physical work environment, and organizational commitment have a positive effect on employee morale. This shows that the higher the compensation and organizational commitment, the higher the employee morale. In an effort to increase the morale of employees of PT Sorik Marapi Geothermal Power Jakarta, the company must pay attention to indicators whose average value is below the average value.
\end{abstract}

Keywords: Financial compensation, non physical work environment, commitment organizational, employee morale.

Abstrak: Tujuan penelitian adalah mengetahui dampak kompensasi finansial, lingkungan kerja non fisik dan komitmen organisasi terhadap semangat kerja karyawan. Penelitian dikerjakan di PT Sorik Marapi Geothermal Power Jakarta. Besar sampel adalah 70 karyawan, menggunakan metode sampel jenuh/sensus. Data dikumpulkan dengan kuesioner. Teknik analisis menggunakan teknik analisis regresi linear berganda. Pengamatan awal menemukan ternyata PT Sorik Marapi Geothermal Power Jakarta ini mempunyai masalah, terkait semangat kerja karyawan. Hal ini dilihat dari tingginya tingkat absensi karyawan. Berlandaskan hasil analisis diketahui bahwa kompensasi finansial, lingkungan kerja non fisik, dan komitmen organisasional berpengaruh positif terhadap semangat kerja karyawan. Hal ini menunjukan bahwa semakin tinggi kompensasi finansial dan komitmen orgnisasional, maka semakin tinggi semangat kerja karyawan. Dalam upaya meningkatkan semangat kerja dari karyawan PT Sorik Marapi Geothermal Power Jakarta, perusahaan sebaiknya harus lebih memperhatikan indikator dengan nilai rata-rata yang lebih rendah dari nilai rata-rata.

Kata kunci: Kompensasi finansial, lingkungan kerja non fisik, komitmen organisasional, dan semangat kerja karyawan. 


\section{INTRODUCTION}

The success of the company is determined in part by the professional management of internal Human Resources (HR). HR is the main asset of the company to achieve the company's vision, mission and goals in a productive, effective and efficient manner. The achievement of company goals is closely related to $\mathrm{HR}$ management. According to Hasibuan $(2014,10)$ HR management is a knowledge that manages labor relations and activities so that they are effective and efficient in working to realize the company's mission. The important role of human resources in the company, apart from expertise or knowledge, is also the employee's own morale which must be directly proportional to the goals set.

Morale is a feeling that allows employees to produce more output through enthusiastic participation in group activities and efforts. Nitisemito in Ardana (2014) states that morale can be defined as working harder. Thus the work is expected to be completed quickly and with better results.

Geothermal is a natural resource in the form of hot water or steam that is formed in the Earth's reservoir through heating of water below the surface by hot rocks. The geothermal system is one of the systems that occurs in geological processes that run in the order of hundreds or even millions of years. Nowadays geothermal brings benefits to humans, both by making manifestations for tourism and for agriculture and livestock. In fact, several countries have utilized geothermal energy for the non-electric sector, including for heating the room, heating water, heating greenhouses, drying agricultural products, heating the soil, drying wood, and other activities. With the potential that Indonesia has, geothermal utilization can be further improved. One of the benefits of geothermal is as an alternative energy source, namely geothermal energy.

Indonesia has enormous geothermal potential. Indonesia is one of the countries where the ring of fire passes. About $40 \%$ or
29,000 MW of the world's total geothermal energy is in Indonesia, because Indonesia is a country that has high volcanic potential. However, this huge potential, the utilization of geothermal energy in Indonesia is still not optimal.

One of the companies operating in the geothermal sector, namely PT. Sorik Marapi Geothermal Power Jakarta. A project developer that focuses exclusively on developing geothermal resources. PT. Sorik Marapi Geothermal Power Jakarta has more than 30 years of experience developing, managing and financing energy and geothermal energy projects.

PT. Sorik Marapi Geothermal Power Jakarta has a vision that is to provide geothermal power in a clean, safe and responsible manner for the interests of the Indonesian people. PT. Sorik Marapi Geothermal Power has 2 different offices, in East Nusa Tenggara and Jakarta, with the aim of developing and accelerating geothermal power projects, with a target of up to 1,000 MW by 2022. PT. Sorik Marapi Geothermal Power Jakarta applies modular power generation technology from Kaishan Manufac-ture, a sponsor of the company's project. This technology makes it possible to develop geothermal resources in a more efficient and environmentally friendly manner.

The company applies values such as; respect others sincerely, fairly, frankly, treat colleagues and the community with dignity and respect individual differences, feelings and contributions. Teamwork is also needed as a core value of the company by sharing ideas and best practices. Helping colleagues to grow personally and professionally. This can promote a healthy and harmonious work environment. From an ownership perspective, setting high performance expectations and holding them accountable for the quality of work and the results achieved as an individual, as a team member, and as a company. Maintain worker productivity by providing regular compensation to maintain company stability. PT. Sorik Marapi Geothermal Power Jakarta responds to new information quickly and 
effectively. The work is dynamic, requiring companies and employees to be open-minded and flexible in their approach.

Companies are responsible for each other's safety. In meeting the company's objectives for quality, cost, and schedule, which do not jeopardize safety. This was created in order to create a sense of loyalty from employees and to be committed to always providing the best ability for the company.

However, in the last two years, the absentee level at PT Sorik Marapi Geothermal Power has increased, this is realized by the company directors (superiors). Several factors make the absentee level due to high company mobility. Employees must visit the head office located in East Nusa Tenggara. However, one important impact that has become a problem for employee morale is the increase in employee absenteeism. The following is a table of information and attendance level data for PT Sorik Marapi Geothermal Power Jakarta obtained from the company.

Tabel 1. 1

ATTENDANCE LEVEL OF PT SORIK MARAPI GEOTHERMAL POWER JAKARTA Period of January - December (2018-2019)

\begin{tabular}{|c|c|}
\hline Month & $\begin{array}{c}\text { Attendance Presentase } \\
(2018-2019)\end{array}$ \\
\hline Jan & $4,13-4,07$ \\
\hline Feb & $4,31-4,50$ \\
\hline Mar & $4,18-4,30$ \\
\hline Apr & $3,75-3,20$ \\
\hline May & $4,16-3,15$ \\
\hline Jun & $3,44-4,40$ \\
\hline Jul & $4,54-4,25$ \\
\hline Aug & $4,4-4,10$ \\
\hline Sep & $4,54-4,13$ \\
\hline Oct & $3,88-4,05$ \\
\hline Nov & $3,24-4,40$ \\
\hline $\mathrm{Dec}$ & $3,13-4,07$ \\
\hline Total & $47,7-48,62$ \\
\hline Avarage & $3,97-4,05$ \\
\hline
\end{tabular}

Table 1.1 describes the high absentee level of PT Sorik Marapi Geothermal Power Jakarta. The reasonable absentee level is below 3 percent. The average employee absenteeism is not good because it is still above 3 percent. Sri Widodo
$(2015,104)$ also explains that morale describes the condition of employees within the scope of work. If the morale is good, the company will also get benefits such as low absenteeism, low employee turnover and increased workforce productivity.

Therefore it is an interesting problem to know what factors can affect the morale of the employees of PT Sorik Marapi Geothermal Power Jakarta. So that employees have enthusiasm when doing their work. With reference to previous journals conducted by I Made Artha Wibawa (2019), the author wants to observe further about this company, and analyze how much influence affects employee morale at PT Sorik Marapi Geothermal Power Jakarta.

This research is a replication of previous research entitled "The Effect of Financial Compensation, Non-Physical Work Environment, Organizational Commitment to Employee Morale with the research object at KSP Tat Twam Asi Denpasar by I Made Artha Wibawa and I Gede Widya Darmawan in 2019. This research lies in the object of research. In previous research, the research object used was KSP Tat Twam Asi Denpasar, while in this study, 70 permanent employees were selected as respondents with the population, namely all employees who work at PT. Sorik Marapi Geothermal Power Jakarta and by using the saturated sampling technique.

\section{Financial Compensation}

According to Bangun (2012, 255) financial compensation is a form of compensation paid to employees in the form of money for the services they provide to the company. On the one hand the company get productivity services from employee work contributions. On the other hand, the company pays employee work contributions which provide productivity to the company. Naturally, financial compensation is routinely given as the "price" the company has to pay for the work of employees. 


\section{Non Physical Work Environment}

Opinions about the non-physical work environment, as stated by Sedarmayanti (2011, 26), are the work environment as a situation related to coworkers or carry-on. The conditions of the work environment can determine the productivity of workers. If the non-physical environment can create a harmonious atmosphere, respect each other, and apply justice in the environment, then workers can increase productivity which has an impact on the company. On the other hand, the non-physical environment cannot create an atmosphere of harmony, mutual respect and apply justice, so workers cannot increase the productivity that impacts the company.

\section{Organizational Commitment}

According to Kreitner and Kinicki (2014, 165) what is meant by organizational commitment is a description of the level at which a person recognizes the organization and is bound by its goals. Organizational commitment can be defined as the degree to which employees are involved in the organization. Organizational commitment is a condition where an employee sides with a particular organization and its goals, and intends to maintain membership in that organization. Loyalty with a feeling of wanting to continue and always be a member of the organization.

\section{Employee Morale}

According to Purwanto $(2013,83)$ states that if people are willing to wholeheartedly serve a job, and job satisfaction and happy family relationships are part of it, it is called work spirit. Morale is also a person's emotional and psychological response to work. Morale affects a person's workload and quality of work.

\section{METHODS}

The form of research used is the causality research study, which examines the causal relationships between the independent variables and the dependent variable (Sekaran and Bougie 2013, 93). Causality research aims to see the impact of independent variables (Financial Compensation, Non-Physical Work Environment, Organizational Commitment) on the dependent variable (Employee Morale).

The sampling technique used saturated sampling. This technique is a sampling technique when all members of the population are sampled, according to Sugiyono $(2015,156)$. Operational Definition of Variables

Financial Compensation (X1) is compensation in the form of nominal money. Financial compensation ranging from monthly salary, fixed and variable allowances, overtime pay, insurance, old age savings, pension, and so on. Financial compensation is routinely given as the "price" that the company pays for the work of its employees. Financial compensation can be further divided into two, namely direct and indirect financial. Company compensation is direct financial in nature in the form of salaries, allowances and all types of payments to employees that are nominalized and given to employees directly.

Non-Physical Work Environment (X2) is a working environment that can determine the productivity of workers. The non-physical work environment can create a harmonious atmosphere, respect each other, and apply justice in the environment, so these workers can increase productivity which has an impact on the company.

Organizational Commitment (X3) is a condition where an employee sides with a particular organization and its goals and intends to maintain membership in that organization. Loyalty with a feeling of wanting to continue and always be a member of the organization.

Morale $(Y)$ is a spiritual condition or behavior of individual workers and groups that causes deep pleasure in the workforce to work more actively and consistently in achieving the goals set by the company. 


\section{RESULTS}

The descriptions of the respondent's data in this study were divided by the researcher into several categories with different criteria, including gender, latest education level and job division.

The Effect of Financial Compensation (X1) on Employee Morale (Y). Based on the results of the study, in Hypothesis 1 the sig value of the Financial Compensation variable is 0.000 with a value of $<0.05$, it can be concluded that $\mathrm{Ho}$ is rejected, namely the Financial Compensation variable has an effect on the Work Spirit of PT.Sorik Marapi Geothermal Power Jakarta employees and the value of $t$ count $>t$ table (8.222> 1.9966), it can be concluded that Ho is rejected, everywhere there is a significant effect of Financial Compensation on the Morale of Employees of PT Sorik Marapi Geo-thermal Power Jakarta. Financial compensation affects employee morale at PT.Sorik Marapi Geothermal Power Jakarta. The existence of satisfaction with the financial compensation received by employees as evidenced by high morale, causes it to affect employees to work more productively.

The Effect of Non-Physical Work Environment (X2) on Employee Morale ( $\mathrm{Y})$. Based on the results of research on Hypothesis 2, the sig value of the Non-Physical Work Environment variable is 0.000 with a value of $<0.05$. So it can be concluded that Ho is rejected, namely the influence of non-physical work environment on Employee Morale at PT Sorik Marapi Geothermal Power Jakar-ta and the value of $t$ count $>t$ table (3.697> 1.9966). So it can be concluded that $\mathrm{Ho}$ is rejected, that is, there is an influence of the non-physical work environment on Employee Morale at PT Sorik Marapi Geothermal Power Jakarta. Non-physical work environment affects the morale of employees at PT. Sorik Marapi Geothermal Power Jakarta. There is a non-physical work environment that can create a harmonious work atmosphere, respect each other, and apply justice in the work environment, can increase worker productivity which has a significant impact on the company.

The Effect of Organizational Commitment (X3) on Employee Morale (Y). Based on the results of research on Hypothesis 3 , the sig value of the Organizational Commitment variable is 0.000 where the value is $<0.05$. So it can be concluded that $\mathrm{Ho}$ is rejected, namely there is an influence of Organizational Commitment on Employee Morale at PT Sorik Marapi Geothermal Power Jakarta and the value of $t$ count> $t$ table (4.744> 1.9966). So it can be concluded that $\mathrm{Ho}$ is rejected, where there is a significant effect on Organizational Commitment on the Morale of Employees of PT Sorik Marapi Geothermal Power Jakarta. Organizational Commitment affects the Work Spirit of Employees at PT.Sorik Mara-pi Geothermal Power Jakarta. The creation of an employee siding with an organization will create loyalty with a feeling of wanting to continue and always be a member of the organization.

\section{CONCLUSIONS}

Financial Compensation has a significant influence on the Morale of Employees at PT. Sorik Marapi Geothermal Power Jakarta. This statement is supported by research conducted by Ni Wayan Quiena Purnamandari and I Wayan Suana (2016), I Made Artha Wibawa and I Gede Widya Darmawan (2019), Desak Ketut Sintaasih (2015) on different objects.

Non-Physical Work Environment has a significant influence on the Morale of Employees at PT. Sorik Marapi Geothermal Power Jakar-ta. This statement is supported by research conducted by Ni Wayan Quiena Pur-namandari and I Wayan Suana (2016), Daniel Alexander Chandra and Roy Se-tiawan (2018) on different objects.

Organizational commitment has a significant influence on Employee Morale at PT. Sorik 
Marapi Geothermal Power Jakarta. This statement is supported by research conducted by I Made Artha Wibawa and I Gede Widya Darmawan (2019), Nashrudin Setiawan and Akh- mad Taufik (2018) on different objects.

The limitations that occur during this research process can be described as follows (1) There are limitations in time, money and manpower, so it is not possible for the questionnaire to be distributed directly to respondents in written form; (2) Respondents who became the sample for this study amounted to 70 people according to the criteria set; (3) Limited data obtained from the object of research. This is be- cause the data is said to be very internal in nature and confidential (confidential) so that some information cannot be given.

Here are some forms of recommendations that might be used as a reference for researchers who want to carry out further research: (1) Expanding the number and using a larger sample for use in further research, so that the results can be more accurate and more representative of the entire population; (2) In further research, it is better to expand the scope of research; (3) Adding independent variables outside the variables that have been used that can affect employee performance.

\section{REFERENCES:}

Ardana, Komang. 2014. Manajemen Sumber Daya Manusia. Graha Ilmu: Yogyakarta.

Bangun, Wilson. 2012. Manajemen Sumber Daya Manusia. Erlangga. Jakarta.

Hasibuan, Malayu S.P. 2016. Manajemen Sumber Daya Manusia (Edisi Revisi). PT Bumi Aksara: Jakarta.

I Wayan Quiena Purnamandari dan I Wayan Suana (2016) Analisis Faktor Motivasi, Kepemimpinan Lingkungan Kerja dan Kompensasi yang Mempengaruhi Semangat Kerja Karyawan Hotel Bali Hyatt Sanur Bali. . E Jornal Manajemen.

I Ketut Manik Swadika Yasa dan I Made Artha Wibawa (2015) Pengaruh Kompensasi Finansial, Komunikasi dan Lingkungan Kerja Fsik terhadap Semangat Kerja Karyawan. E-Jurnal Manajemen Universitas Udayana. 2015. Bali.

I Nyoman Bayu Putra Mahardika dan I Made Artha Wibawa 2019. Pengaruh Budaya Organisasi, Kepuasan Kerja dan Komitmen Organisasional terhadap Organizational Citizenship Behaviour pada Karyawan. Jurnal Manajemen Universitas Udayana. 8(1).

Kreitner, Robert dan Angelo Kinicki. 2014. Perilaku Organisasi. Edisi 9. Buku 1. Jakarta: Salemba Empat.

Michael Valentine dan Bambang Heryadi 2016. Loyalias Karyawan pada CV Trijaya Manunggal. Agora 4(2).

Muhammad Annas 2015. Analisisis Kompensasi Keuangan dan Non Keuangan terhadap Produktivitas

Karyawan pada Mitra Departemen Store Jajag Banyuwangi. Jurnal Pendidikan, 7(1).

Novia Dani Pramusinto, Ahmad Daerobi dan Sri Mulyaningsih 2019. Permintaan dan Penawaran Tenaga Kerja serta Pengangguran di Indonesia. Seminar Nasional Bisnis Magister Manajemn. Univesitas Sebelas Maret (UNS) Surakarta.

Purnamandari, Ni Wayan Quiena dan dan I Wayan Suana. 2014. Pengaruh Analisis Faktor Motivasi, Kepemimpinan, Lingkungan Kerja, Komunikasi, Penempatan Karyawan, dan Kompensasi yang Mempengaruhi Semangat Kerja Karyawan Hotel Bali Hyatt Sanur Bali. 3(8)

Putranto, Danang Indra. 2012. Pengaruh Komunikasi Internal, Kompensasi Kerja, dan Lingkungan Kerja Terhadap Kepuasan Kerja Karyawan pada PT. Kimia Farma Plant Semarang. Diponegoro Journal of Social and Politic.

Sedarmayanti. 2011. Manajemen Sumber Daya Manusia. Reformasi Birokrasi dan Manajemen Pegawai Negeri Sipil, Cetakan Kelima, PT Refika Aditama, Bandung.

Sekaran, Uma dan Bogie 2013. Research Methode for Business: Skill Building Approach. John Wiley and Sons. New York.

Sugiyono. 2016. Metode Penelitian Kuantitatif, Kualitatif dan R\&D. Bandung: PT Alfabet. 
Tanod, NA 2019 Pengaruh Kompensasi dan Disiplin Kerja terhadap Kinerja Karyawan di Yuta Htel Mando. Jurnal Risert, Ekonimi, Manajeme, Bisnis dan Akyntansi, 7(1).

Triyana, I. N. Y., and I. M. A. Wibawa. , 2014. Pengaruh Gaya Kepemimpinan Transformasional, Insentif Finansial dan Komitmen Organisasional terhadap Semangat Kerja Karyawan The Stones Legian Bali Hotel. EJurnal Manajemen Universitas Udayana, 3(11).

Wasnury, Rendra, et al. 2015. Pengaruh Kompensasi Finansial dan Lingkungan Kerja terhadap Semangat Kerja Karyawan pada Perusahaan Daerah Air Minum (Pdam) Tirta Kampar Bangkinang Kota. Jurnal Online Mahasiswa Fakultas Ekonomi Universitas Riau, 2(1),

Wita Farla, Yuliansyah M Diah dan Supardi a Bakri 2019. Pengaruh Kompensasi Finansial dan NonFinansial terhadap Komiten Karyawan. Jurnal Manajemen dan Kewirausahaan, 7(1). 
